\title{
O Trabalho com o Gênero Carta Pessoal na Educasão de Jovens e Adultos
}

\author{
Joseval dos Reis MIRANDA* \\ Lindolfo Santos RAMALHO**
}

* Mestre e Doutor em Educação pela Universidade de Brasília (UnB). Mestrado em Máster en Promoción de la Salud Sexual pela Universidad Nacional de Educación a Distancia (UNED). Atualmente é professor e pesquisador Adjunto II, em Regime de Dedicação Exclusiva da Universidade Federal da Paraíba (UFPB). Contato: josevalmiranda@yahoo.com.br.

** Mestre (2016) pelo Programa de Mestrado Profissional em Letras - Profletras da Universidade Federal da Paraíba (UFPB). Professor da rede municipal de Ensino de Mamanguape - PB. Contato: lindolfosantosramalho@gmail.com.

\section{Resumo:}

O presente artigo aborda sobre o processo de escrita da carta pessoal por estudantes da Educação de Jovens e Adultos. Em um primeiro momento, tecemos reflexões sobre os gêneros textuais como estratégia para o ensino da escrita e, em seguida mais especificamente, expomos sobre a carta pessoal. Os nossos aportes teóricos constituíam-se de obras como Marcuschi (2002, 2008, 2010), Antunes (2003, 2009), Dolz, Noverraz e Schneuwly (2004), Cavalcante (2013) e Oliveira (2014). A pesquisa foi desenvolvida por meio da abordagem qualitativa, na qual utilizamos a pesquisa participante, fazendo uso da observação participante e da roda de conversa. Foram colaboradores da pesquisa cinco estudantes da Educação de Jovens e Adultos, sendo quatro do sexo feminino e um do sexo masculino. Os resultados das análises apontaram que a produção escrita da carta pessoal, elaborada por meio da sequência didática desenvolvida por Dolz, Noverraz e Schneuwly (2004), possibilitou aos participantes da pesquisa a aquisição de conhecimentos linguístico-discursivos necessários à construção do gênero carta pessoal, bem como contribuiu para o reconhecimento e, ao mesmo tempo, para a superação das principais dificuldades por eles apresentadas durante o processo de escrita da carta pessoal.

\section{Palavras-chave:}

Gêneros textuais. Carta pessoal. Educação de Joven e Adultos.

Signum: Estudos da Linguagem, Londrina, v. 21, n. 3, p. 328-345, dez. 2018 


\section{O Trabalho com o Gênero Carta Pessoal na Educação de Jovens e Adultos}

Joseval dos Reis Miranda; Lindolfo Santos Ramalho

\section{Palavras Iniciais}

Uma vez que o assunto é a produção de um texto escrito, percebemos que surge, por parte dos/as estudantes, um descontentamento e/ou desinteresse, quando são convidados a participar de tais atividades. Contudo, os livros didáticos abordam um grande número de gêneros textuais com a finalidade de serem trabalhados em sala de aula como conteúdo pedagógico.

Nesse intuito, o presente texto é resultado de uma pesquisa, realizada durante o ano letivo de 2016, que teve como objetivo geral compreender como o/a professor/a de Língua Portuguesa poderá contribuir para a melhoria do processo de escrita na Educação de Jovens e Adultos, fazendo uso da escrita da carta pessoal. Tivemos como participantes diretos desta pesquisa cinco estudantes do $2^{\circ}$ segmento da Educação de Jovens e Adultos de uma Escola Municipal do Vale do Mamanguape (PB), de uma turma de $7^{\mathrm{a}} / 8^{\mathrm{a}}$ séries que, por livre e espontânea vontade, se disponibilizaram em participar.

Não poderíamos deixar de mencionar que, na pesquisa desenvolvida, utilizamos a abordagem qualitativa, por meio da pesquisa participante. E todos os nomes dos/as participantes mencionados nesse trabalho são fictícios, com a finalidade de preservação da sua identidade.

O texto trata, inicialmente, dos aspectos sobre os gêneros textuais como estratégias para o ensino da escrita, fazendo também a relação com a utilização da carta pessoal nos dias atuais. Em seguida, discutimos sobre a estrutura da carta pessoal como subsídio para outros gêneros.

Por fim, apresentamos as dificuldades e as estratégias de escrita para a produção da carta pessoal utilizadas na pesquisa, com o intuito de que as ponderações aqui anunciadas provoquem "novas" reflexões com vistas ao aperfeiçoamento do trabalho de escrita e rescrita por meio da carta pessoal na Educação de Jovens e Adultos.

\section{GÊneros Textuais como Estratégia para o Ensino da Escrita}

A partir do conhecimento de que os gêneros textuais são fenômenos ligados ao nosso cotidiano e que se constituem como estruturas de comunicação oral e escrita, passam a ser compreendidos, como diz Marcuschi (2010, p. 22), 
Partimos do pressuposto básico que é impossível se comunicar verbalmente a não ser por algum gênero, assim como é impossível se comunicar a não ser por algum texto. Em outros termos, partimos da ideia de que a comunicação verbal só é possível por algum gênero textual.

Contudo, um procedimento que acreditamos ser importante antes de se iniciar um trabalho com gêneros textuais seria apresentar para alunas e alunos uma breve definição entre tipos e gêneros textuais; assim, tomando como base a definição empregada por Marcuschi (2010, p. 23), temos:

Usamos a expressão tipo textual para designar uma espécie de sequência teoricamente definida pela natureza linguística de sua composição (aspectos lexicais, sintáticos, tempos verbais, relações lógicas). Em geral, os tipos textuais abrangem cerca de meia dúzia de categorias conhecidas como: narração, argumentação, exposição, descrição, injunção. Na sequência, o autor define gênero textual, usamos a expressão gênero textual como uma noção propositalmente vaga para referir aos textos materializados que encontramos em nossa vida diária e que apresentam características sócio comunicativas definidas por conteúdos, propriedades funcionais, estilo e composição característica. Se os tipos textuais são apenas meia dúzia, os gêneros são inúmeros. [...] seriam: telefonema, sermão, carta comercial, carta pessoal, romance, bilhete, reportagem jornalística, aula expositiva, receita culinária etc.

Com isso, a definição mostra que os gêneros textuais estão por toda a parte, ou seja, estão presentes em todo momento comunicativo do qual o ser humano participa, seja ele verbal ou não verbal.

Por essa definição, vemos a importância da intervenção adequada da professora e do professor na condução do conhecimento sobre o tema (gêneros textuais), uma vez que a intenção primeira é aproximar cada vez mais o gênero estudado ao cotidiano estudantil, e fazer esse público perceber que as diversas atividades por ele vivenciadas em seu dia a dia são sempre permeadas por um determinado gênero textual que, de certa forma, adequa-se a cada momento comunicativo por ele vivenciado.

Para tanto, a compreensão e a produção de um texto não podem ser entendidas como um simples exercício corriqueiro de sala de aula que envolva leitura e escrita, mas como um conjunto de fatores que envolvam esse evento comunicativo; assim diz Cavalcante (2013, p. 18):

Para compreender e produzir qualquer texto, é necessário mobilizar conhecimentos, não apenas linguísticos, mas também todos os outros conhecimentos adquiridos com a convivência social, que nos informam e nos tornam aptos a agir nas diversas situações e eventos da vida cotidiana.

Dessa maneira, ao apresentar algo que será estudado por estudantes em sala de aula, faz-se necessário, como atividade inicial, mostrar a importância desse evento comunicativo (OLIVEIRA; TINOCO; SANTOS, 2014, p. 33), pois uma ação de linguagem só tem sentido 
se atender ao interesse do usuário (neste caso, o/a aluno/a) e estiver vinculada a um fato relativo ao mundo social do qual ele faz parte.

Visto dessa maneira, entendemos que o ensino dos gêneros textuais só fará sentido para estudantes quando estes/as entenderem que a aquisição desse conhecimento se concretizará na forma de realização pessoal e profissional no meio ao qual está inserido.

Com a inclusão de outros eventos, o ensino da produção textual constitui-se em uma atividade bastante pertinente quando o interesse é melhorar a escrita estudantil. Para tanto, podemos destacar os gêneros textuais que segundo Marcuschi (2010. p. 19):

Fruto de trabalho coletivo, os gêneros contribuem para ordenar e estabilizar as atividades comunicativas do dia a dia. São entidades sociodiscursivas e formas de ação social incontornáveis em qualquer situação comunicativa. [...] Caracterizam-se como eventos textuais altamente maleáveis, dinâmicos e plásticos. Surgem emparelhados a necessidades e atividades socioculturais, bem como na relação com inovações tecnológicas, o que é facilmente perceptível ao se considerar à quantidade de gêneros textuais hoje existentes em relação a sociedades anteriores à comunicação escrita.

Todavia, os gêneros evoluem para dar conta dos eventos de comunicação que surgirem ao longo de nossa existência, viabilizando os interlocutores a compreensão no ato de se comunicar e interagir com o próximo.

Segundo os Parâmetros Curriculares Nacionais da Língua Portuguesa - PCN (BRASIL, 1997) $5^{a}$ a $8^{a}$ séries, "O domínio da língua, oral e escrita é fundamental para a participação social afetiva, pois é por meio dela que o homem se comunica, tem acesso à informação, expressa e defende pontos de vista, partilha ou constrói visões de mundo, produz conhecimento". Pensando assim, cresce a responsabilidade quanto à condução do saber, pois é preciso mostrar aos/às estudantes o quão gratificante é adquirir conhecimento, integrando-os, ao mesmo tempo, à sua experiência de vida.

Nessa conjuntura, a utilização dos gêneros como ferramenta de estudo, visando ao desenvolvimento da leitura, torna-se viável quando voltada para elaboração e compreensão de um texto que envolva uma prática de linguagem, como podemos ler em Antunes (2009, p. 59):

O estudo dos gêneros permitiria aos alunos perceber como a elaboração e a compreensão de um texto resulta da conjunção de fatores internos à língua e de fatores externos a ela; externos porque ancorados numa situação social que envolva uma prática de linguagem.

Ainda sobre o uso do gênero como objeto de estudo direcionado a um evento de comunicação entre seus participantes, Bronckart (2001 apud MARCUSCHI, 2008, p. 22) afirma:

Os textos são um objeto legítimo de estudo e que a análise de seus níveis de organização permite trabalhar a maioria dos problemas relativos à língua em todos os seus aspectos. E 
completa dizendo que, os gêneros são instrumentos de adaptação e participação na vida social e comunicativa.

Essa afirmativa do autor é compreensível, haja vista que, de acordo com a necessidade de comunicação, os gêneros vão se adequando para melhor atender ao propósito comunicativo daquele a quem o utiliza, ou seja, o gênero é algo que vai surgindo ou se aperfeiçoando conforme a sociedade vai se modernizando.

De acordo com Dolz, Noverraz e Schneuwly (2004), o "gênero é um instrumento". Os autores complementam:

Um instrumento media uma atividade, dá-lhe certa forma, mas esse mesmo instrumento representa também essa atividade, materializa-a. Dito de outra maneira: as atividades não mais se presentificam somente em sua execução. Elas existem, de certa maneira, independentemente desta, nos instrumentos que as representam e, logo, significam-nas. O instrumento torna-se, assim, o lugar privilegiado da transformação dos comportamentos: explorar suas possibilidades enriquecê-las, transformá-las são também maneiras de transformar a atividade que está ligada à sua utilização (p. 20-21).

Contudo, para se produzir um texto dentro de um gênero previamente selecionado, deve-se, antes de qualquer atividade, mostrar para os/as estudantes a importância desse aprendizado como realização concreta de leitura e escrita com o propósito de ampliar os seus conhecimentos, fazendo-se úteis ao seu cotidiano.

Isso posto, o exercício da escrita através da prática diária será capaz de transmitir para os/as estudantes mais confiança quanto ao exercício da produção de um texto escrito, assim como esse público poderá discorrer sobre um determinado tema com mais habilidade e aptidão.

Precisamos, também, ensinar para nossos/as estudantes que os gêneros não são conteúdos vinculados e existentes apenas nos livros, mas constituem-se como meios utilizados por todos nós em nosso dia a dia e que, mesmo sem percebermos, estamos constantemente fazendo uso desse instrumento de comunicação tão valioso presente em nosso meio.

Em se tratando ainda de tipos textuais, Marcuschi (2002) faz uma observação bastante interessante quanto à maneira, segundo ele equivocada, usada nos livros didáticos e em nosso dia a dia quando empregamos a expressão "tipo de texto", referindo-nos a um determinado "gênero textual". Marcuschi (2002, p. 25) diz:

Quando alguém diz, por exemplo, 'a carta pessoal é um tipo de texto informal, ele não está empregando o termo 'tipo de texto' de maneira correta e deveria evitar essa forma de falar. Uma carta pessoal que você escreve para sua mãe é um gênero textual, [...]. Assim, um texto é em geral tipologicamente variado (heterogêneo). Vê-se o caso da carta pessoal, que pode conter uma seqüência narrativa (conta uma historinha), uma argumentação (argumenta em função de algo), uma descrição (descreve uma situação) e assim por diante. 
Nesse eixo interpretativo, entendemos que um gênero textual é composto de tipos textuais, ou seja, são os tipos textuais que compõem a estrutura sequencial dos gêneros textuais, assim como nos mostra a citação anterior, visto que num único gênero textual pode ocorrer mais de um tipo textual e, dependendo do gênero em ação, um tipo textual irá sobressair-se em relação aos demais.

Para mais uma definição de gênero, recorremos a Koch (2014 p. 55), ao afirmar que "todas as nossas produções, quer orais, quer escritas, se baseiam em formas-padrão relativamente estáveis de estruturação de um todo a que denominamos gêneros". 'Tal definição aproxima-se bastante das citadas anteriormente por outros autores. Utilizando-se da expressão "gêneros discursivos", Cavalcante (2013, p. 44), conceitua gêneros da seguinte forma:

São padrões sociocomunicativos que se manifestam por meio de textos de acordo com necessidades enunciativas específicas. Trata-se de artefatos constitutivos sociocognitivamente para atender aos objetivos de situações sociais diversas. Por esse motivo, eles apresentam relativa estabilidade, mas seu acabamento foi (e continua sendo) constituído historicamente.

Com isso, é possível compreender que, a cada nova situação comunicativa, haverá um gênero discursivo que trate desse enunciado, com o objetivo de atender às diversas situações sociais que se constituem ao longo do tempo.

Contudo, chamando a atenção para os gêneros como prática social e histórica para o ser humano, diz Marcuschi (2002, p. 19): "Já se tornou trivial a idéia de que os gêneros textuais são fenômenos históricos, profundamente vinculados à vida cultural e social".

Desta forma, o ensino de gêneros textuais deve ser visto como um evento de produção de escrita adequado a cada situação de aprendizagem, capaz de possibilitar aos/às estudantes, aqui em especial para a Educação de Jovens e Adultos, além do aprendizado, a compreensão de que tal gênero possa lhe ser útil no seu cotidiano.

\section{O Ensino do Gênero Carta Pessoal como Meio de Comunicação em Dias AtUAIS}

Não podemos negar que, ao longo do tempo, a carta pessoal vem perdendo espaço para outros gêneros atualmente considerados mais ágeis e usuais; entretanto, ainda encontrarmos pessoas que utilizam a carta como meio de dar uma notícia, buscar soluções para um problema, fazer um pedido etc.

Contudo, em tempos atuais, alguns programas de televisão que vão ao ar em todo o território nacional ainda fazem uso de cartas como interação entre apresentadores e o público-alvo a quem se destina. Podemos citar como exemplo o programa "Globo Rural", que utiliza, além da carta tipo e-mail, a carta manuscrita, pelas quais pessoas ligadas ao meio rural buscam informações sobre pragas que atacam as lavouras, tipos de solos adequados para determinadas culturas ou como iniciar um negócio, entre outros. 
Como atividade radiofônica, na cidade de Mamanguape-PB, há uma rádio local que apresenta para os seus ouvintes um quadro intitulado "A vida como ela é"; neste, as pessoas enviam cartas à redação do programa na esperança de encontrar uma solução para seus problemas.

Diante disso, mesmo em meio aos avanços tecnológicos, a escrita da carta ainda acontece, uma vez que muitas pessoas veem na carta um instrumento simples, porém ainda utilitário no ato de se comunicar.

É necessário compreender que a carta pessoal, além de ser vista como um meio utilizado para melhorar a escrita do emissor na produção de textos escolares, deve ser vista, também, como gênero textual capaz de desenvolver a comunicação entre pessoas que se encontram distantes com a finalidade de trocar confidências entre si, obter informações de alguém distante: certamente, a carta pessoal, quando escrita de próprio punho, denota um sentido de proximidade entre seus interlocutores.

Em se tratando da escrita da carta pessoal, é importante que o emissor tenha conhecimento do tipo de linguagem que deverá utilizar, tendo em vista a quem será destinada a carta, pois, sem dúvida, é o destinatário que irá determinar o nível de linguagem empregada nessa situação comunicativa. Assim, tomamos como exemplo uma instituição de ensino ou uma autoridade; a linguagem usada será a formal. Por outro lado, se a carta for escrita para alguém conhecido, como um amigo ou um familiar, a linguagem neste caso é de cunho informal.

Quanto à linguagem, escrever cartas poderá exigir, tanto do emissor quanto do receptor, certo conhecimento linguístico para saber que tipo de linguagem deverá empregar e como se estrutura, conforme Cavalcante (2013, p. 44), "para que as comunicações se realizem de modo satisfatório, pois, do contrário, não teríamos condições de criar formas de interação absolutamente inéditas e nem seríamos compreendidos, caso isso ocorresse". Sabendo que, em uma eventual resposta à carta recebida, o receptor passará a ser, agora, o emissor, evidenciando o real propósito comunicativo.

Portanto, na pesquisa desenvolvida com estudantes da Educação de Jovens e Adultos fazendo uso dos gêneros textuais, além de levá-los/as a tomar conhecimento da estrutura e da funcionalidade da carta pessoal, desejamos envolver esse público em situações concretas de maneira que consigam chegar a um resultado consciente das atividades de escrita que realizarem.

\section{A Estrutura do Gênero Textual Carta Pessoal como Subsídio para a Escrita de Outros GÊnERos}

No espaço escolar ou fora dele, seria interessante, tanto para estudantes quanto para falantes letrados, que todos tivessem conhecimento de como se estrutura uma carta pessoal. Ainda que não seja um gênero utilizado com frequência na atualidade, aprender sua estrutura possibilita ao leitor adquirir subsídios para a produção de outros gêneros, como 
um memorando, a carta aberta, a carta comercial e o próprio e-mail, uma vez que a carta pessoal possui um padrão fixo no que se refere a aspectos estruturais. Lembramos, também, que juntamente ao bilhete, a carta serve de base para o e-mail como mostra Marcuschi (2002, p. 21): “O e-mail (correio eletrônico) gera mensagens eletrônicas que têm nas cartas (pessoais, comerciais, etc.) e nos bilhetes os seus antecessores. Contudo, os gêneros eletrônicos são gêneros novos com identidades próprias...".

Com isso, para que se possa adquirir um bom conhecimento da estrutura de um gênero, teríamos como atividade inicial segundo Antunes (2009, p. 58), "O estudo detalhado das estruturas de composição dos textos ou sua forma composicional, quer dizer, conheceríamos que blocos compõem determinado gênero; que formas assumem e em que sequência esses blocos são distribuídos".

Isso ocorre com a finalidade de reconhecer, no texto, o tipo de gênero que foi utilizado, como também ser conhecedor, no momento de produzir um texto, de qual estrutura usar para o gênero textual solicitado, ou seja, o trabalho de intervenção de professores/as, na produção escrita, é sem dúvida importante, pois, nas idas e vindas da reescrita dos textos, é possível perceber as dificuldades e junto a estudantes procurar saná-las.

Para tanto, o domínio do gênero carta pessoal contribuirá para que o alunado possa adquirir habilidades para produzir outros gêneros. Dessa forma, para que os/as estudantes possam, a cada dia, melhorar sua escrita, eles/as precisam entender que o ato da escrita está presente nas diversas funções comunicativas que envolvem a comunidade na qual está inserido, como nos mostra Antunes (2003, p. 47-48):

Se prestarmos atenção à vida das pessoas nas sociedades letradas, constatamos que a escrita está presente, como forma constante de atuação, nas múltiplas atividades dessas pessoas - no trabalho, na família, na escola, na vida social em geral - e, mais amplamente, como registro do seu patrimônio científico, histórico e cultural. Dessa forma, toda escrita responde a um propósito funcional qualquer, isto é, possibilita a realização de alguma atividade sociocomunicativa entre as pessoas e está inevitavelmente em relação com diversos contextos sociais em que essas pessoas atuam.

Sendo assim, a escrita se constitui como ferramenta utilizada para as mais diversas funções que envolvem a comunicação entre as pessoas, pois além de ser usada para realizar um convite, oferecer um aviso, solicitar uma ajuda, escrever cartas, bilhetes, receitas médicas e de culinária, entre outras, funções, independentemente do meio social do qual fazem parte interlocutores e interlocutoras, é fato que a escrita torna-se algo que possibilita às pessoas interagir com mais propriedade, visando a um melhor relacionamento entre elas.

Destarte, voltamos a dizer que desenvolver ou se deparar com um texto cuja estrutura se conhece é bastante importante, uma vez que um determinado gênero pode não conter uma de suas propriedades, ou ser escrito no formato de outro gênero. Entretanto poderá ser reconhecido pelos/as leitores/as, visto que estes/as já sabem como este gênero se estrutura, como mostra Marcuschi (2002, p. 30): 
Por exemplo, uma carta pessoal ainda é uma carta, mesmo que a autora tenha esquecido de assinar o nome no final e só tenha dito no início: 'querida mamãe'. Uma publicidade pode ter um formato de um poema ou de uma lista de produtos em oferta; o que conta é que divulgue os produtos e estimule a compra por parte dos clientes ou usuários daquele produto.

Sendo assim, esperamos que os/as estudantes da Educação de Jovens e Adultos, após o trabalho de escrita com a carta pessoal, seja capaz de compreender as diversas funções que um gênero textual é capaz de exercer em seu cotidiano.

pode-se dizer que o trabalho com gêneros textuais é uma extraordinária oportunidade de se lidar com a língua em seus mais diversos usos autênticos no dia-a-dia. Pois nada do que fizermos lingüisticamente estará fora de ser feito em algum gênero (MARCUSCHI, 2002, p. 35).

Com outras palavras, o autor afirma que nada do que escrevemos ou até mesmo falamos fugirá à classificação de um determinado gênero, visto que todas as atividades que praticamos em nosso cotidiano emanam de algum gênero.

\section{Uma Possibilidade de Proposta de Trabalho com a Carta Pessoal na Educação De Jovens e Adultos}

Para início de conversa, apresentamos um esquema que envolve as etapas a serem percorridas para este fim. Porque esta proposta é fruto de uma pesquisa que realizamos com estudantes da $7^{\mathrm{a}}$ e $8^{\mathrm{a}}$ séries da Educação de Jovens e Adultos, desenvolvida por uma sequência didática da qual fizemos uso e obtivemos êxito junto à maioria dos participantes.

\section{ESQUEMA DE SUGESTÃO PARA A ESCRITA DA CARTA PESSOAL}

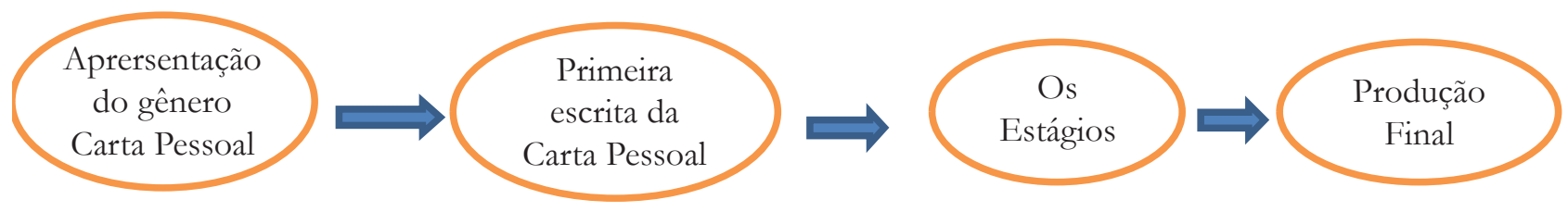

\section{Apresentação do gênero carta pessoal}

A apresentação consiste em mostrar aos/às estudantes da Educação de Jovens e Adultos, de preferência para turmas de $7^{\mathrm{a}} / 8^{\mathrm{a}}$ séries, como será desenvolvido o trabalho de produção escrita da carta pessoal. Para tanto, o/a professor/a poderá, por exemplo, convidar os/as estudantes a participarem de uma Roda de Conversa, que se constitui por um espaço aberto, no qual seus participantes são convidados a fazer parte de encontros promovidos e 
elaborados pelo/a professor/a: na ocasião, ele/a fará a apresentação do gênero textual do qual irá trabalhar.

$\mathrm{Na}$ oportunidade, o/a professor/a poderá mostrar um pouco da história da carta nas práticas comunicativas mediadas pela escrita; em seguida, distribuir entre os/as estudantes cópias de cartas pessoais, para que possam conhecer sua composição estrutural, que se organiza da seguinte forma: local e data, saudação e vocativo, exposição do conteúdo, despedida e assinatura, bem como deve explicar que a carta pessoal caracteriza-se por estar relacionada a pessoas íntimas, como marido e mulher, namorado e namorada, amigos/as e pessoas da família. Por conta disso, ou seja, dessa proximidade entre os interlocutores, a linguagem empregada na maioria das correspondências é de cunho informal.

Essa atividade dificilmente poderá ser aplicada em um único encontro, pois, dependendo do número de aulas que o/a professor/a possuir na turma, ela poderá se estender por pelo menos dois ou três encontros, tudo para que o/a estudante possa se preparar o melhor possível para participar da sua primeira escrita da carta pessoal.

Nessa etapa, o/a professor/a deverá convidar os/as estudantes a realizarem uma leitura compartilhada e, em seguida, investigar se seriam capazes de reconhecer cada parte que compõe a estrutura desse gênero, o tipo de linguagem utilizada, o tema abordado em cada carta, enfim, provocá-los/as para ter uma ideia do que conseguiram assimilar até ali.

\section{Primeira escrita da carta pessoal}

Nesse momento, os/as estudantes terão a oportunidade de redigir o seu primeiro texto escrito com a intenção de mostrar o que conseguiram compreender sobre o gênero textual carta pessoal, considerando que, mesmo sendo um gênero de fácil entendimento, muitos dos participantes, jamais escreveram uma carta para alguém; por isso, no momento da produção, poderão surgir vários problemas com potencial de dificultar a escrita desse texto.

No entanto, mesmo com algumas dificuldades que certos/as estudantes poderão apresentar, cada um, de acordo com seu conhecimento e capacidade adquiridos, terá condições de produzir um texto que, no momento de sua elaboração, poderá não ser o ideal. Não é essa a intenção do trabalho, nessa etapa, mas que ele/a possa compreender a temática adotada e escrever conforme o que apreendeu sobre as características do gênero escolhido. É preciso considerar que essa etapa só será concluída quando o/a estudante escrever a sua produção final.

\section{Os estágios}

Os estágios compõem uma das etapas do processo de produção textual, de grande relevância para o bom andamento do trabalho de escrita da carta pessoal, haja vista ser constituído para que professores/as desenvolvam a sua intervenção didático-pedagógica, 
que será por eles/as utilizados para ajudar os/as estudantes a identificarem os problemas de escrita que surgirão quando submetidos à primeira escrita da carta pessoal. Quanto à quantidade de estágios, esses ocorrerão conforme a necessidade apresentada pelos/as estudantes em relação às dificuldades que eles demonstrarem durante a atividade de escrita do texto. Para tanto, poderão ser divididos da seguinte forma:

$1^{\text {o }}$ Estágio - Nele poderão ser analisados aspectos relacionados ao conteúdo temático, ou seja, observar se o/a estudante conseguiu compreender o tema solicitado pelo/a professor/a, discorrendo ou não de maneira adequada sobre o que lhe fora proposto para ser desenvolvido como trabalho de escrita de seu texto.

$\mathrm{Na}$ sequência, outro aspecto importante a ser analisado é quanto à informatividade, ou seja, a observar se a informação passada para o interlocutor é passível ou não de compreensão, isto é, se a mensagem passada para aquele a quem a carta será destinada estará coerente com o que foi solicitado pelo/a professor/a. Na continuidade, há ainda outros aspectos a serem analisados, como o estilo e o tipo de linguagem empregada pelo/a estudante, que poderá variar entre formal ou informal, sendo predominante, nesse gênero textual, a linguagem informal.

Por fim, caberá ao/à professor/a, como trabalho de intervenção, desenvolver atividades de acordo com os problemas de maior ocorrência que ele detectou na análise feita na carta de cada estudante, podendo, de preferência, utilizar os problemas apresentados por eles/as mesmos/as, ou seja, utilizar partes dos textos dos/as estudantes, sendo criterioso/a ao não deixar transparecer os seus autores e, em seguida, escrevê-los na lousa, antes de, juntos, pedir para que identifiquem onde está o problema e como resolvê-lo. Após essa etapa, o/a professor/a poderá desenvolver muitas outras atividades nesse sentido. Este estágio poderá ser realizado em dois encontros.

$2^{\circ}$ Estágio - Nesse segundo estágio, o/a professor/a poderá analisar os aspectos linguísticos e discursivos da produção escrita da carta pessoal dos/as estudantes. No que trata dos aspectos linguísticos, poderão ser detectados problemas de acentuação, pontuação, o emprego de letras maiúsculas e minúsculas, de ortografia, de dígrafos, entre outros aspectos gramaticais que sejam relevantes ou que poderão aparecer no decorrer da análise.

Em relação aos aspectos discursivos, poderão ser observados a aplicação da coesão e da coerência textuais, a concordância verbal e a nominal, a colocação pronominal, além de conectivos como preposição, conjunção, tempos e modos verbais, entre outros que poderão surgir, conforme o decorrer da análise de cada texto. Após cada análise, ou seja, linguística e discursiva, somos enfáticos em pedir para que o/a professor/a, ao utilizar-se da intervenção didático-pedagógica, possa começar, fazendo uso dos problemas apresentados pelos/as estudantes em seus textos, expostos na lousa ou em recortes transcritos pelo/a professor/a e repassados a eles/as, de maneira que, em conjunto, sejam capazes de identificar as inadequações apresentadas em cada texto, bem como ter a oportunidade de corrigi-los juntos. 
Outro recurso que poderia ser utilizado pelo/a professor/a seria o bilhete, pois, fazendo uso de bilhetes, o/a professor/a poderá indicar para o/a estudante o que precisará mudar em seu texto, sem, contudo, mostrar como realmente deverá fazer, uma vez que o incentivo será para que, ao identificar o problema, ele/a possa compreender que, de fato necessita melhorar gradativamente a sua forma de escrita. Este estágio também poderá ser realizado em dois encontros.

$3^{\mathbf{o}}$ Estágio - O terceiro estágio poderá ser reservado para o desenvolvimento da primeira reescrita da carta pessoal. Nesse momento, é importante a intervenção do professor como incentivador, visto que, através da reescrita, o/a estudante terá a oportunidade de refazer o seu texto, observando os problemas que foram apontados em sua primeira escrita da carta pessoal, procurando melhorá-los. Entretanto, o ideal é que essa atividade só seja aplicada depois que o/a professor/a tiver trabalhado com o/a estudante os problemas de maior relevância, identificados em cada produção escrita. Para este estágio, dois encontros serão suficientes.

\section{A produção final da carta pessoal}

Nesse momento, o/a aluno/a da Educação de Jovens e Adultos terá a oportunidade de mostrar se evoluiu ou não em relação às etapas do processo de sequência didática aos quais ele será submetido. A produção final é entendida como uma soma de tudo o que o/a estudante aprendeu e será posto em prática a partir de sua última produção textual escrita do gênero textual carta pessoal. Essa produção escrita poderá ser usada pelo/a professor/a como atividade de nota, levando-se em conta o nível de superação apresentado pelo/a estudante durante todo o processo pelo qual participou.

\section{Para finalizar, a nossa sugestão de possibilidade de trabalho}

Gostaríamos de lembrar aos professores e às professoras que essa é apenas uma sugestão, sequenciada por um esquema didático-pedagógico que mostra como trabalhar em sala de aula a produção escrita da carta pessoal com estudantes da $7^{\mathrm{a}} / 8^{\mathrm{a}}$ séries da Educação de Jovens e Adultos, com a finalidade de ajudá-los/as; além de melhorar a sua escrita, oferecer-lhes condições de superar cada dificuldade por eles/as enfrentada, proporcionando-lhes uma aprendizagem segura e pautada na descoberta e na resolução dos problemas. Para tanto, vale ressaltarmos que não se trata de receita ou de um método a ser seguido; cada professor/a pode alterar a presente proposta a partir da sua necessidade, contexto e leituras tanto sobre a Educação de Jovens e Adultos, os gêneros e a carta pessoal. 


\section{As dificuldades apresentadas por estudantes da Educação de Jovens e Adultos na produção da carta pessoal}

Nessa etapa da pesquisa, após a primeira escrita da carta pessoal e como desenvolvimento dos estágios mencionados anteriormente, o objetivo era detectar as principais dificuldades apresentadas pelos/as os/as estudantes que se comprometeram a participar do trabalho de escrita do gênero carta pessoal, levando-se em conta a comparação entre a produção inicial e a produção final, com o propósito de perceber se houve ou não uma evolução significativa na sua forma de escrita durante o desenvolvimento desse projeto. De acordo com Dolz, Noverraz e Schneuwly (2004, p. 102), "a análise das produções orais ou escritas dos alunos guiada por critérios bem definidos, permite avaliar de maneira bastante precisa em que ponto está a classe e quais são as dificuldades encontradas pelos alunos".

Nesse caso, além de estar atento às dificuldades apresentadas pelos/as estudantes, deve-se ter em mente que os critérios que forem utilizados precisam ser claros e objetivos para facilitar a compreensão do/a estudante.

Temos notado até aqui que, apesar do empenho e dedicação que estes/as estudantes demonstraram na primeira etapa de produção da carta pessoal, os problemas de escrita são cada vez mais visíveis e preocupantes, pois são alunos/as que, em pouco tempo, estarão ingressando no Ensino Médio.

Percebemos que houve muitos "problemas" em todos os textos produzidos - não somente nestes, mas também nos demais, que não foram diretamente analisados, mas possuem problemas idênticos a estes.

Outro aspecto bastante relevante nesse trabalho de escrita foi a desistência de alguns alunos, por alegarem não ter o que escrever e afirmarem: "Não tenho cabeça e nem paciência pra isso"; ou "Homi deixe esse negócio de escrita pra lá, vamo fazer outra coisa...". Depoimentos como esses condizem com o que disse Antunes (2003, p. 45):

A atividade da escrita é, então, uma atividade interativa de expressão, (ex-, 'para fora'), de manifestação verbal das idéias, informações, intenções, crenças ou dos sentimentos que queremos partilhar com alguém, para, de algum modo, interagir com ele. Ter o que dizerer é, portanto, uma condição prévia para o êxito da atividade de escrever.

Portanto, se alguém tem dificuldades em manusear a palavra, a ponto de não conseguir desenvolver uma frase ou expressão que possa informar algo, e se, por outro lado, não busca esse aprendizado, essa pessoa apresentará muitos problemas ao tentar se comunicar com alguém por meio de uma escrita bem elaborada.

Finalizamos, apreensivos, esta etapa, porém com expectativas de que tais problemas apresentados pelos/as estudantes na construção do texto escrito poderão ser devidamente compreendidos, ser melhorados ao longo dessa atividade, visto que, através de exercícios desenvolvidos e elaborados que envolvam questões dessa ordem, eles irão perceber onde 
não foram bem, tendo, a partir de então, condições de refazê-los observando as alterações necessárias exigidas pelo texto, tornando-se, de acordo com o PCN (BRASIL, 1997, p. 66), "um escritor competente, capaz de revisar e reescrever o próprio texto, até que possa ser considerado satisfatório para o momento".

\section{Estratégias de escrita para a produção da carta pessoal na Educação de Jovens e Adultos}

Após analisar todas as produções e ter detectado os problemas apresentados na produção inicial dos/as estudantes, percebemos que o que fora discutido sobre o gênero carta pessoal não foi suficiente para que os/as estudantes compreendessem todas as características desse gênero. Por isso, apresentamos, a partir de agora, algumas propostas de atividades que foram realizadas com os/as alunos/as, com o objetivo de melhorar e, ao mesmo tempo, ampliar os seus conhecimentos para futuras produções de textos escritos.

Módulo 1 - Neste módulo, tratamos com mais afinco dos aspectos estruturais que compõem a carta pessoal, uma vez que, após análise da produção inicial de cada estudante, ficou evidente que, de uma maneira geral, eles/as demostraram certa dificuldade no momento de organizar cada aspecto ao gênero, pois cada etapa cumpre uma função específica e a condição final do texto vai depender de como se respeitou cada uma dessas funções (ANTUNES, 2003, p. 54). Com isso, explicamos para eles/as a necessidade de falarmos um pouco mais sobre o gênero carta pessoal. Para tanto, levamos para os/as estudantes algumas atividades que pudessem ajudá-los/as a compreender melhor como se estrutura o gênero carta pessoal.

Entretanto, antes de lhes entregar as cartas com as quais trabalhamos, consideramos melhor iniciar essa reflexão fazendo uso dos elementos que compõem a estrutura desse gênero textual, utilizando de partes de seus próprios textos onde havia problemas dessa ordem. Inicialmente, separamos alguns trechos e os apresentamos como exercício, de maneira que toda a turma participou da correção. Ressaltamos que todos os trechos de cartas expostos na lousa tiveram, mesmo que fictícios, os nomes preservados.

Ao terminar essa etapa da atividade, distribuímos entre eles/as uma cópia de uma carta pessoal no intuito de reforçar os pontos em que precisavam melhorar. Para tanto, pretendíamos com essa atividade que, ao receberem as suas primeiras produções, fizessem uma comparação entre elas, detectando os problemas para não mais cometê-los em sua primeira reescrita.

Módulo 2 - Nesse módulo, tratamos de conteúdos referentes aos aspectos linguísticos dos textos produzidos, tais como: acentuação, pontuação, letras maiúsculas e minúsculas, inadequações ortográficas. Iniciamos chamando a atenção dos/as estudantes para questões relacionadas à pontuação e à acentuação. Assim, como nos módulos anteriores, também utilizamos palavras retiradas dos seus próprios textos. Primeiramente, separamos 
algumas palavras com problemas de acentuação como remedio, aniversario, ola, esta (V. de ligação), otimo, saida, ta, ai, convida-la, "acontecéra".

Após expostas na lousa, mostramos para eles/as que toda palavra da nossa língua possui uma sílaba tônica, porém nem todas são acentuadas, mas as apontadas na análise são acentuadas e, juntos, pedimos que, ao pronunciarem tais palavras, procurassem descobrir onde estava a sílaba tônica de cada uma delas; também lhes explicamos que os acentos usados são o acento grave da crase, o acento circunflexo e o acento agudo. Depois de um pequeno espaço de tempo, descobriram quais sílabas deveriam ser acentuadas e, em seguida, um deles se dirigiu até a lousa, acentuando-as adequadamente.

Quanto à pontuação, explicamos que este recurso é importante para separar palavras e frases, dando a elas maior compreensão e sentido. $\mathrm{Na}$ sequência, expusemos a seguinte frase retirada da carta de Joseane (linhas 05/07): "Meu querido Amigo Paulo como você esta Ficou melhor da Zica Graças a deus eu fiquenhe melhor [...]". Não demorou muito para que alguns alunos pudessem identificar que, após o nome Paulo, deveria ter uma vírgula; e entre os verbos está e ficou, uma interrogação, pois disseram: "isso é uma pergunta", assim como, depois da palavra Zica e, finalmente depois da palavra melhor um ponto final.

Com relação às letras maiúsculas e minúsculas, mostramos mais duas frases da carta de Joseane (linhas 09/11): "Graças a deus [...]" e "[...] tar tomando algum Remedio Para Ficar melhor eu Fiquenhe Boa mas eu ainda sentor um Pouco de dores [...]". E, uma da carta de Josu (linha 01) “mamanguape em o Dia 13/06/16”. A partir daí, explicamos que devemos sempre iniciar frases com a letra inicial maiúscula, escrever nomes de pessoas, de lugares, títulos de livros, nomes de disciplinas etc. e, jamais no meio das frases, quando essas palavras são grafadas com letra inicial minúscula. Na sequência, mais uma vez pedimos para que eles identificassem as palavras que estavam escritas de maneira inadequada e as corrigissem.

Em se tratando das inadequações ortográficas, em todos os textos encontramos problemas da ordem de: "fiquenhe”, "tar", "sentor", "Lir", "seos”, "espolsa”, "lembo", "trabalhado", "Sito", "bricadeira”, "Thau” "isto”, "Agente”, “com”. Depois de escrevê-las na lousa sentindo a necessidade de ajudá-los a melhorar a sua escrita, apresentamos uma atividade envolvendo questões sobre acentuação, bem como de pontuação.

Módulo 3 - Nesse módulo, tratamos de conteúdos referentes aos aspectos discursivos dos textos produzidos, como questões de coesão e de coerência textuais, visto que alguns textos apresentaram ou a ausência ou a presença inadequada de algum conectivo como, por exemplo, o uso dos pronomes "mim" em lugar de "me", da contração da preposição "de mais os artigos definidos os e as", na frase "[...] os nosso divertimento as nossa saída", da carta de Beatriz (linhas 05/06). Para tanto, explicamos para eles que um texto coeso é aquele que apresenta boa conexão em suas partes, ou seja, há "amarração" de todos os elementos para a produção de sentido. Assim, quando não há coesão, ou seja, há ausência de elementos como pronomes, conjunções, preposições, artigos, tempos e modos verbais, por exemplo, pode ocorrer a quebra de coesão textual. 
No trecho a seguir, retirado da carta de Samarah (linha 03), ocorreu à ausência da conjunção, o que implicou na construção de um trecho sem coesão; vejamos: "Hoje é uma data muito especial seu aniversário estou the mandando essa carta [...]". Antes de iniciar algumas perguntas, tratamos de mostrar a eles/as alguns tipos de conjunções e quando deveriam ser usadas; depois disso, expusemos a frase na lousa e solicitamos para que observassem quais das conjunções estudadas poderiam ser usadas para dar mais ênfase à oração. Após algum tempo, chegaram à conclusão de que ficaria entre a palavra "especial" e "seü", a conjunção coordenativa explicativa "pois" seguida do verbo ser " $\hat{e}$ " e, entre "aniversário" e "estou", a conjunção coordenativa explicativa "por isso".

A presença de um determinado conectivo de maneira inadequada pode forçar o texto a ficar sem coesão, como na troca da conjunção adversativa "mas" pelo advérbio de intensidade "mais"; entretanto, quanto à coerência, pode não haver perda, visto que elas são foneticamente parecidas, como aparece nos trechos das cartas de Samarah (06/07): “[...] $A$ gente passava cada momentos bons mais depois você foi embora fiquei muito triste. mais A vida é assim [...]". E de Bruna (linhas 03/04): "Oi! Marta quanto tempo que nós não nos falamos nem lembro a última vez: Mais mudando de assunto, [...]". Assim, como as demais, todas estas atividades propostas nos módulos, de fato, preparam para a produção da carta pessoal.

\section{A produção final: apresentação e análise}

Nessa produção, observarmos se os estudantes foram capazes de superar as dificuldades que tiveram na escrita inicial e que ainda persistiram em sua primeira reescrita, bem como se houve o surgimento de um problema novo evidenciado através da análise da produção final de cada um deles.

Fazendo uma comparação entre a produção inicial e a produção final, podemos afirmar que a estudante Beatriz, uma de nossas participantes, obteve uma melhora considerável, visto que conseguiu identificar os principais problemas existentes na versão inicial e buscou resolvê-los, mesmo que não tenha corrigido todos. Em linhas gerais, é possível dizer que Samarah avançou em sua escrita, uma vez que, a partir das atividades realizadas em sala de aula, ela pôde identificar vários problemas que apareceram na produção inicial e procurou resolvê-los de forma consciente, apesar de ainda persistirem alguns problemas.

Com relação à produção final de Joseane, podemos afirmar que, dentro de suas limitações, dentre todos/as que participaram do processo de escrita da carta pessoal, foi ela quem mais evoluiu; assim, percebemos que, se o trabalho com a sequência didática for bem aplicado, o resultado obtido é, de fato, o de superação da maioria dos problemas existentes na produção escrita de um texto.

Fazendo também uma comparação entre a produção inicial e a produção final de Josu, assim como os demais textos analisados até então, ele conseguiu avançar em alguns aspectos; entretanto, talvez por falta de maior conhecimento de leitura e escrita ele, não foi 
capaz de ampliar o conteúdo de sua carta, ficando tão somente numa mera repetição de orações de mesmo sentido.

E, por fim, comparando as produções inicial e final, no geral, Bruna foi quem menos apresentou problemas: isso provou que ela tinha maior intimidade com os aspectos linguísticos e discursivos presentes em nossa língua e, por isso, fez uso de uma linguagem de fácil compreensão.

Assim sendo, a partir do trabalho de escrita da carta pessoal, desenvolvido com tais estudantes da Educação de Jovens e Adultos, acreditamos que, por meio de uma sequência didática elaborada segundo Dolz, Noverraz e Schneuwly (2004), há uma possibilidade didático-pedagógica, como sugestão para os/as professores/as de Língua Portuguesa que atuam nessa modalidade de ensino, orientando-os/as a trabalhar a carta pessoal, como proposta de superar problemas relacionados à produção escrita de textos por estes/as estudantes.

\section{Considerações Finais}

A Educação de Jovens e Adultos é uma modalidade que, pouco a pouco, vai ganhando seu espaço e seu reconhecimento na sociedade como meio indispensável de educar aqueles/as que nela estão inseridos/as, cumprindo o seu papel de incentivar a cidadania e equidade social.

Com isso, a oportunidade oferecida aqueles/as que não tiveram condições de aprender e que, por algum motivo, pararam de estudar e, hoje, voltaram à sala de aula, não se constitui em um favor e, sim, um dever, ou seja, uma reparação para uma dívida social que o país por muito tempo negou.

Quanto ao tema proposto, desenvolver um trabalho de escrita através do gênero textual carta pessoal em uma turma de $7^{\mathrm{a}} / 8^{\mathrm{a}}$ séries de Educação de Jovens e Adultos, tomando como base a sequência didática, buscávamos tão somente possibilitar, ao/à estudante dessa modalidade, um aprimoramento de sua escrita, uma vez que vêm-se tornando cada vez mais frequentes os problemas relacionados a esse conteúdo.

Diante disso, a proposta de intervenção foi desenvolvida, conforme a sequência didática proposta pela Escola de Genebra por Dolz, Noverraz e Schneuwly (2004), bem como a apresentação do gênero com o qual eles/as trabalharam, primeiramente por meio de uma escrita inicial; após esta etapa, foi feita a aplicação de atividades empregadas através dos módulos, pelos quais tivemos a oportunidade de elaborar exercícios, visando a ajudar o/a estudante a reconhecer o problema detectado em sua primeira produção escrita; em seguida, solicitamos que eles/as produzissem a sua primeira reescrita e, por fim, a produção final, momento em que o/a estudante teve a chance de procurar sanar em definitivo alguns problemas que ainda restaram das produções anteriores.

Gostaríamos de salientar que houve um avanço considerável na escrita de alguns alunos e alunas que, ao receberem as suas cartas para mais uma escrita, perceberam várias inadequações que, por sua vez, não tinham aparecido em sua escrita final. Com isso, a 
resposta para este objetivo foi dada pela fala dos próprios estudantes. Como disse Samarah: "Eu sei como se escreve essas palavras, mas por causa do nervoso erree"; disse Joseane: "Professor, mais que vergonha! A minha carta não tem um sinal de pontuação se quer"; quando afirmou Josu: "Rapą! A minha carta ficou toda misturada!"; por fim, Bruna comentou: "Professor, esse trabalho era pra ser feito pelo menos duas vezes por ano, ai eu queria ver se a gente não aprendia a escrever direitinho!".

Assim sendo, acreditamos que esse trabalho desenvolvido de escrita e reescrita em uma turma de Educação de Jovens e Adultos contribuiu na melhoria na forma de escrita desses/as estudantes; em parte, inquietos, pois, por algum motivo, nem todos conseguiram atingir o que fora proposto; porém estamos convictos de que não se esgotam aqui todas as análises apresentadas a respeito do que foi pesquisado neste trabalho, tampouco pode ser dado como completo e acabado, visto que, considerando serem infinitas as informações, este se encontra aberto a novas análises a partir de outros contextos e outros atores sociais que estejam envolvidos.

\section{REFERÊNCIAS}

ANTUNES, I. Aula de português: encontro \& interação. São Paulo: Parábola, 2003.

ANTUNES, I. Lingua, texto e ensino: outra escola possível. São Paulo: Parábola, 2009.

BRASIL. Ministério da Educação. Secretaria de Educação Fundamental. Parâmetros Curriculares Nacionais: $5^{\mathrm{a}}$ a $8^{\mathrm{a}}$ série. Brasília: SEF; MEC, 1997.

CAVALCANTE, M. M. Os sentidos do texto. 1. reimp. São Paulo: Contexto, 2013.

DOLZ, J.; NOVERRAZ, M.; SCHNEUWLY, B. Seqüências didáticas para o oral e a escrita: apresentação de um procedimento In: DOLZ, J.; SCHNEUWLY, B. Gêneros orais e escritos na escola. Tradução de Roxane Rojo e Glaís Sales Cordeiro. Campinas: Mercado de Letras, 2004. p. 81-108.

MARCUSCHI, L. A. Gêneros textuais: definição e funcionalidade. In: DIONÍSIO, A. P. et al. (Org.). Gêneros textuais e ensino. Rio de Janeiro: Lucerna, 2002.

MARCUSCHI, L. A. Produção textual, análise de gêneros e compreensão. São Paulo: Parábola, 2008.

MARCUSCHI, L. A. Gêneros textuais: definição e funcionalidade. In: DIONÍSIO, A. P. et al. (Org.). Gêneros textuais e ensino. São Paulo: Parábola, 2010.

OLIVEIRA, M. do S.; TINOCO, G. A.; SANTOS, I. B. de A. Projetos de letramento e formação de língua materna. Natal: EDUFRN, 2014. 